\title{
Factors Affecting Implementation of Pain Reassessment in Inpatient Unit at Balaraja Regional Hospital
}

\author{
Kristina Everentia Ngasu*, Restiana Restiana \\ Department of Medical-Surgical Nursing, Nursing High School, Yatsi, Tangerang, Banten, Indonesia
}

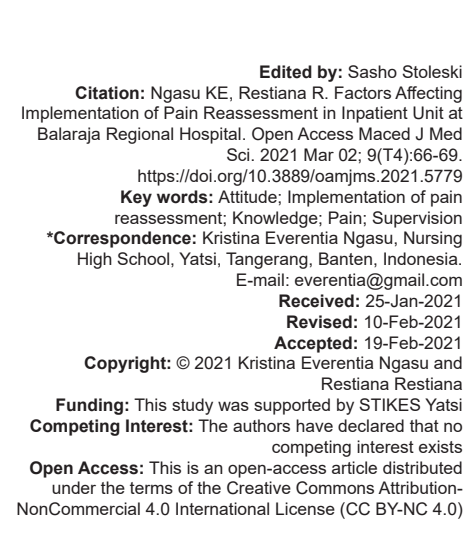

Introduction

Pain is a sensation of individual discomfort [1]. In life, humans need comfort because this is a fundamental aspect of human life [2]. In the context of nursing, nurses should control and monitor the level of pain through pain reassessment. One of the patient's needs is pain sensation free. Patients often experience pain, especially pain after undergoing surgery.

According to the World Health Organization (WHO) [3], in some types of pain conditions, the mechanism of pathophysiological pain is not well understood or cannot be demonstrated. All patients with pain must be treated with pharmacological or nonpharmacological techniques regardless of whether the underlying cause can be identified or not. The inability to determine the underlying cause should not be a reason to conclude that pain is simulated.

One aspect of pain management is done by assessing pain, namely, assessment of pain problems that can be done with a history of pain, as well as complaints of pain such as the location of pain, pain intensity, quality, and time of attack [4]. Accurate pain assessment is essential for effective pain management. Pain reassessment is the reassessment of pain done to patients who are treated for more than a few hours and shows the presence of pain [5].

The results of a study conducted by Ehwarieme et al. [6], concerning factors affecting the utilization of pain assessment tools among nurses in selected tertiary hospitals in Edo state of Benin city. The results showed that $20.4 \%$ routinely used pain assessment tools. Factors such as a shortage of nursing staff, lack of knowledge about pain assessment tools, patient cultural beliefs about pain, lack of implementation by the nursing service unit, and unavailability of pain assessment tools are identified as barriers to the use of pain assessment tools. There is no significant relationship between the nurse academic status and the use of pain assessment tools.

According to research conducted by Ross et al. [7], on the outpatient performance improvement project: Basic assessment of compliance with pain assessment standards shows the results that only $38 \%$ did a reassessment within the 30 min interval 
required by clinical policy. Out of a total of 151 cases, the overall compliance rate for pain reassessment based on all requirements (pain intensity scale, $30 \mathrm{~min}$ requirements, pain location, side effects of medication, and patient education documented or observed was $28 \%$ ). Pain reassessment was documented at an average time of 25 min after the initial assessment.

The results of a preliminary study with 10 respondents, $60 \%$ of nurses knew about pain reassessment and $40 \%$ did not know about pain reassessment. The reality in the field that refers to the implementation of pain reassessment is still very rarely done by nurses in hospitals. Only $60 \%$ implement the pain reassessment in patients who experience pain.

The purpose of this study is to get a picture about nurses' knowledge, attitude and supervision, and its relationship to the implementation of pain reassessment.

\section{Methods}

A cross-sectional study was conducted among nurses from inpatient unit at Balaraja Regional Hospital. The study was carried out on July 2019. The population was 36 nurses, who worked in inpatient unit, at Balaraja Regional Hospital. This study was applying total sampling technique. The inclusion criteria were nurses, who worked in inpatient unit at Balaraja Regional Hospital and gave written informed consent, were included in the study. The exclusion criteria were nurses, who work in the unit, other than inpatient unit and who did not give written informed consent or refuse to participate in the study, were excluded from the study Notoatmodjo, S.,(2012) [8], Supardi, S. \& Rustika, (2013) [9].

Data were collected using a self-made questionnaire, which passed validity and reliability test. The final version of the questionnaire had 45 questions subdivided into five categories. The first part of the questionnaire included background data of the respondents (age, sex, education, and working time in clinical experience). The second part of the questionnaire was for their knowledge about pain, included definition of pain, pain reassessment, cause of pain, goal of pain reassessment, type of pain tools, time for pain reassessment, and pain drug. The third part of the questioner was their attitude in implementation of pain management, included how they see the important of patient complain about pain, consistency in doing pain reassessment, and documentation and how they see the nursing care implication of pain reassessment. The fourth part of questioner was for supervision, included how they see, their superior did the planning for supervision, control them in doing pain reassessment, warning if not match, guide, and motivate them, and give reward and punishment. The fifth part of the questioner was about their implementation in doing pain reassessment based on procedure or not, gave patient education about pain and pay attention, and action to the patient complaint about pain.

All collected data were checked for completeness. Data were entered on the computer using a database developed for data entry on Microsoft Office Excel program. Data were then transferred to the computer program IBM SPSS (Statistical Package for the Social Science). Descriptive statistics including frequencies and percentages were displayed to summarize the data, while Chi-square test was used to assess the relationship between categorical variables.

\section{Results}

All respondents involved in this research were the staff nurses in inpatient unit at the Balaraja Regional Hospital.

Table 1: Demographic characteristic of respondents at Balaraja Regional Hospital $(n=36)$

\begin{tabular}{lll}
\hline Demographic characteristic & $\mathrm{f}$ & $\%$ \\
\hline Age & 3 & \\
$17-25$ & 24 & 6.3 \\
$26-35$ & 9 & 25 \\
$36-45$ & & \\
Gender & 19 & 52.8 \\
$\quad$ Female & 17 & 47.2 \\
$\quad$ Male & & \\
Educational & 31 & 86.1 \\
$\quad$ Diploma & 5 & 13.9 \\
$\quad$ Bachelor & & \\
Working of time in clinical & & 38.9 \\
experiences (years) & 14 & 55.6 \\
$\quad<4$ & 20 & 2.8 \\
5-9 & 1 & 2.8 \\
10-14 & 1 & \\
15-19 & &
\end{tabular}

Table 1 shows that among of 36 respondent, the highest percentage comes from the age group of 26-35 years (24 or 66.7\%), gender of female (19 or $52.8 \%)$, working of time in clinical experience of 5-9 years (20 or $55.6 \%$ ), and had a diploma's degree (31 or $86.1 \%$ ).

Table 2: Knowledge, attitude, supervision, and pain reassessment implementation characteristic of respondents at Balaraja Regional Hospital $(n=36)$

\begin{tabular}{lll}
\hline Knowledge characteristic & f & $\%$ \\
\hline Knowledge & 11 & 38.9 \\
$\quad$ Lack of knowledge & 25 & 61.1 \\
$\quad$ Good knowledge & & \\
Attitude & 12 & 33.3 \\
$\quad$ Lack of attitude & 24 & 66.7 \\
$\quad$ Good attitude & & \\
Supervision & 10 & 27.8 \\
$\quad$ Lack of supervision & 26 & 72.2 \\
$\quad$ Good supervision & & 30.6 \\
Pain reassessment implementation & 11 & 69.4 \\
$\quad$ Lack of implementation & 25 & \\
\hline
\end{tabular}

Table 2 shows that the majority of respondent's knowledge about pain re-assessment is in good category (25 or $61.1 \%$ ), for attitude on implementation of pain reassessment among respondents is in good category ( 24 or $66.7 \%$ ), Table 2 shows that the majority 
of supervision on implementation of pain reassessment among respondents is in good category (26 or $72.2 \%$ ), the majority of respondent's implementation of pain reassessment among respondents is in good category (25 or $69.4 \%$ ).

\section{Bivariate Analysis}

This research uses Chi-square test for bivariate analysis. As shown in Table 3, knowledge was not related to pain reassessment implementation. As shown in Table 4, attitude was significant related

Table 3: Cross-tabulation based on knowledge and pain reassessment implementation of respondents at Balaraja Regional Hospital $(n=36)$

\begin{tabular}{|c|c|c|c|c|c|c|c|}
\hline \multirow[t]{3}{*}{ Variable knowledge } & \multicolumn{6}{|c|}{ Pain reassessment implementation of respondents } & \multirow[t]{3}{*}{$\mathrm{p}$ value } \\
\hline & \multicolumn{2}{|c|}{$\begin{array}{l}\text { Pain reassessment } \\
\text { implementation }\end{array}$} & \multicolumn{2}{|c|}{$\begin{array}{l}\text { Good in pain } \\
\text { reassessment } \\
\text { implementation }\end{array}$} & \multicolumn{2}{|c|}{ Total } & \\
\hline & $f$ & $\%$ & $f$ & $\%$ & $f$ & $\%$ & \\
\hline Lack of knowledge & 3 & 8.3 & 11 & 30.6 & 14 & 38.9 & 0.467 \\
\hline Good of knowledge & 8 & 22.2 & 14 & 38.9 & 22 & 61.1 & \\
\hline Total & 11 & 30.5 & 25 & 69.5 & 36 & 100 & \\
\hline
\end{tabular}

to pain reassessment implementation. As shown in Table 5, supervision was significant related to pain reassessment implementation.

Table 4: Cross-tabulation based on attitude and pain reassessment implementation of respondents at Balaraja Regional Hospital $(n=36)$

\begin{tabular}{|c|c|c|c|c|c|c|c|}
\hline \multirow[t]{3}{*}{ Variable attitude } & \multicolumn{6}{|c|}{ Pain reassessment implementation of respondents } & \multirow[t]{3}{*}{$P$ value } \\
\hline & \multicolumn{2}{|c|}{$\begin{array}{l}\text { Pain } \\
\text { reassessment } \\
\text { implementation }\end{array}$} & \multicolumn{2}{|c|}{$\begin{array}{l}\text { Good in pain } \\
\text { reassessment } \\
\text { implementation }\end{array}$} & \multicolumn{2}{|c|}{ Total } & \\
\hline & $f$ & $\%$ & $\mathrm{f}$ & $\%$ & $\mathrm{f}$ & $\%$ & \\
\hline Lack of attitude & 7 & 19.4 & 5 & 13.9 & 12 & 33.3 & 0.020 \\
\hline Good of attitude & 4 & 11.1 & 20 & 55.6 & 24 & 66.7 & \\
\hline Total & 11 & 30.6 & 25 & 69.4 & 36 & 100 & \\
\hline
\end{tabular}

p statistical alpha $<0.05$.

\section{Discussion}

\section{Relationship between Knowledge and Implementation of Pain Reassessment showed that there was No Relation in this Study}

The results of this study were $38.9 \%$ of respondents who lacked knowledge of the implementation of pain reassessment. Based on the analysis of the result, the majority of respondent with lack of knowledge are in level one practical nurse. It means that they are still needed more information or in-service training about pain assessment. Based on the results of filling out the questionnaire on the point worked according to standard operating procedure (SPO), the average respondent who answered as worked according SPO as much as $56.7 \%$, this is likely due to lack of knowledge where respondents did not know the SPO consequently respondents could not carry out the implementation of pain re-assessment properly. This study was in line with research conducted by Handayani et al. [10] about the relationship of nurses' knowledge and motivation with the implementation of SPO for pain reassessment in Adult Inpatient Installation at Waluya Sawahan Hospital, Malang.

Table 5: Cross-tabulation based on supervision and pain reassessment implementation of respondents at Balaraja Regional Hospital $(n=36)$

\begin{tabular}{|c|c|c|c|c|c|c|c|}
\hline \multirow[t]{3}{*}{ Variable supervision } & \multicolumn{6}{|c|}{ Pain reassessment implementation of respondents } & \multirow[t]{3}{*}{$P$ value } \\
\hline & \multicolumn{2}{|c|}{$\begin{array}{l}\text { Pain } \\
\text { reassessment } \\
\text { implementation }\end{array}$} & \multicolumn{2}{|c|}{$\begin{array}{l}\text { Good in pain } \\
\text { reassessment } \\
\text { implementation }\end{array}$} & \multicolumn{2}{|c|}{ Total } & \\
\hline & $f$ & $\%$ & $f$ & $\%$ & $f$ & $\%$ & \\
\hline Lack of supervision & 6 & 16.7 & 4 & 11.1 & 10 & 27.8 & 0.039 \\
\hline Good of supervision & 5 & 13.9 & 21 & 58.3 & 26 & 72.2 & \\
\hline Total & 11 & 30.6 & 25 & 69.4 & 36 & 100 & \\
\hline
\end{tabular}

\section{Relationship between Attitude and} Implementation of Pain Reassessment showed that there was No Relation in this Study

This means that with a good attitude, nurses' will implement good performance in nursing care and in the implementation of pain reassessment. This is in accordance with the theory of attitude which says that through action and learning a person will gain trust and attitude toward something which, in turn, will influence her/his attitude in giving care. Someone's work behavior is greatly influenced by attitude at work. While attitude in responding to problems are influenced by one's personality. This study is in line with research conducted by Togubu et al. [11] about the factors associated with documenting nursing care in a regional hospital in the island of Tidore Islands. This study is also in line with the research by Bawelle et al. (2015) [12] about the relationship between knowledge and attitudes of nurses and the implementation of patient safety at Inpatient Unit of Liun Kandage Hospital" which say that there is a relationship between nurses' attitudes and nursing care with a $p$ value of 0.000 .

\section{Relationship between Supervision and Implementation of Pain Reassessment showed that there was No Relation in this Study}

Supervision is needed to improve the work of nurses in carrying out the implementation of pain reassessment. Supervision is carried out correctly which is a form of support from the environment to improve the quality of work of nurses so that the quality of the implementation of pain review can be better. The ability of the head nurse in this case is expected to carry out the briefing function through good supervision activities to guarantee the quality of nursing services. The results of this study are in line with Yanti and Warsito's research [13] on the relationship of nurse characteristics, motivation, and supervision with the quality of the documentation of the nursing care process which states that supervision has a relationship in improving the quality of nursing care 
with $p=0.041$. This research in line with the research conducted by Ginting and Sinaga (2019) [14], about the relationship between the implementation of the head nurses' supervision with the documentation of nursing care at Martha Friska Pulo Brayan Hospital. Research results show that there is a relationship between the supervision of the head of the room with documentation of nursing care, $p=0.003$.

Limitation of the study was respondents rushed in filling out the questionnaire.

\section{Conclusion}

This research concludes that there is no relationship between respondent knowledge and implementation of pain reassessment and there is a relationship between respondent's attitude and supervision with the implementation of pain reassessment in inpatient unit at Balaraja Regional Hospital.

Nursing Management, to provide this information or in-service training for respondents to increase knowledge and attitude and to have a tight supervision, especially for respondents at practical nurses level one $(\mathrm{PK}-1)$ so that it is expected that the implementation of pain re-assessment will be better.

Recommendation for further research can be written in this section.

\section{Acknowledgments}

The authors give special thanks to the management of Balaraja Regional Hospital, also to nurses who participate in this research. The authors also give thanks and appreciate STIKES Yatsi for the support they provided.

\section{References}

1. Sutanto AV, Fitriana Y. Basic Human Needs. Yogyakarta: Pustaka Baru Press; 2017.

2. Andarmoyo S. Concept and Nursing Process of Pain. Jogjakarta: Ar-Ruzz Media; 2013.

3. World Health Organization. Persisting Pain in Children Package: WHO Guidelines on the Pharmacological Treatment of Persisting Pain in Children with Medical IIInesses. Printed in France. Geneva: World Health Organization; 2012. https://doi. org/10.7748/ncyp2013.10.25.8.15.s22

4. Hidayat AA, Musrifatul U. Introduction to Basic Human Needs. $2^{\text {nd }}$ ed. Jakarta: Salemba Medika; 2014

5. Yudiyanta NK, Novitasari RW. Assesment nyeri. J CDK. 2015;42(3);214-34

6. Ehwarieme TA, Amiegheme FE, Ogbogu CJ. Perceived factors affecting utilization of pain assessment tool among nurses in selected tertiary hospital in Benin City Edo State. J Res Nurs Midwifery. 2018;7(1):1-10.

7. Ross A, Feider L, Nahm ES, Staggers N. An outpatient performance improvement project: Basic assessment of adherence to pain reassessment standards. Mil Med. 2017;182(56):e1688-95. https://doi.org/10.7205/milmed-d-16-00104 PMid:29087912

8. Notoatmodjo S. Health Research Methodology. Jakarta: Rineka; 2012.

9. Supardi S, Rustika R. Nursing Research Methodology Textbook Jakarta: Trans Info Media; 2013.

10. Handayani SU,Ariani NL, Maemunah N. The relationship between nurses' knowledge and motivation with the implementation of operational procedure (SPO) standard for the assessment of pain in the adult inpatient room of Waluya Sawahan Hospital Malang. J IImiah Keperawatan. 2017;2(3):612-21.

11. Togubu F, Korompis GE, Kaunang WP. Factors related to documentation of nursing care at the Tidore Kepulauan city regional hospital. J Kesmas. 2019;8(3):60-8.

12. Bawelle SC, Sinolungan JS, Hamel RS. Relationship between nurses' knowledge and attitudes with patient safety implementation in the inpatient room of Liun Kandage hospital. J Keperawatan. 2015;1(1):1-7.

13. Yanti RI, Warsito BE. Relationship between nurse characteristics, motivation, and supervision with the quality of nursing care process documentation. J Manajemen Keperawatan. 2013;1(2):107-14.

14. Ginting and Sinaga. The relationship between the supervision of the Head Nurse and the documentation of nursing care at Martha Friska Pulo Brayan Hospital. J Darma Agung Husada. 2019;5(1):32-7. 